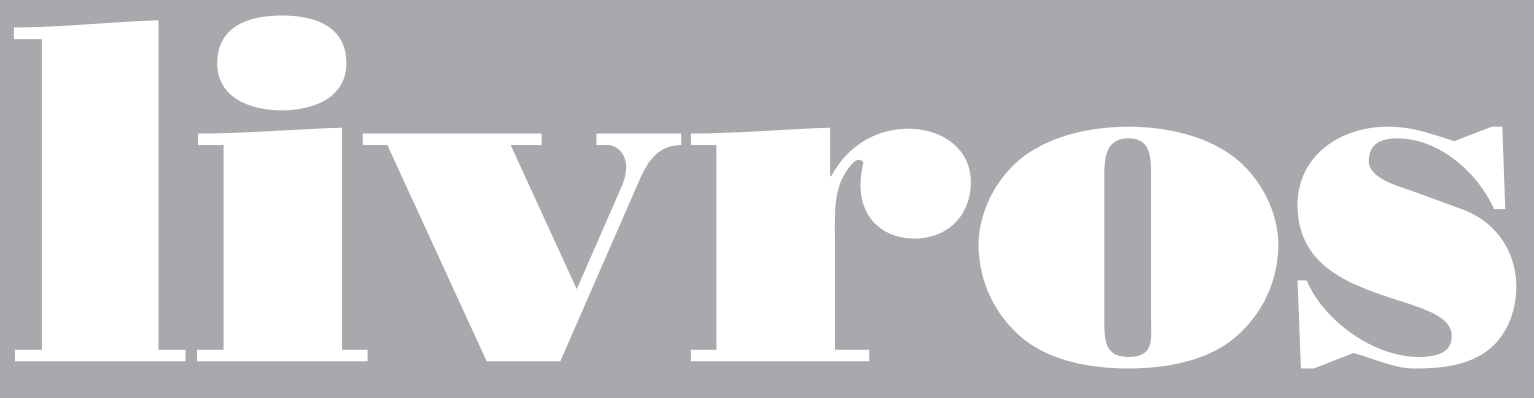





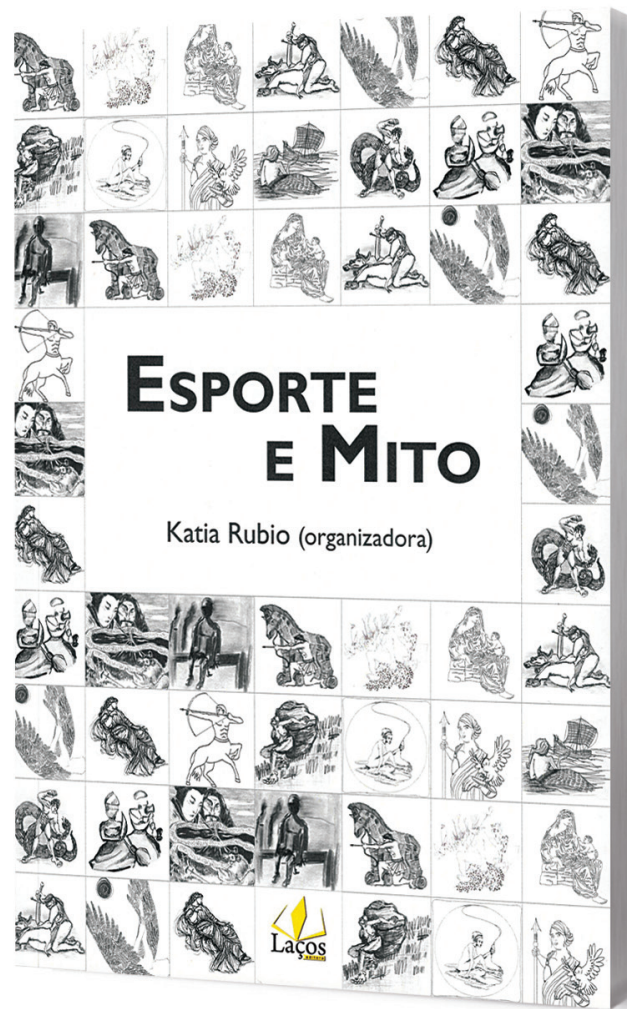

\section{Dos mitos e ideais gregos - e da sua importância para o presente crepuscular}

\section{Jorge Olímpio Bento}

Esporte e mito, de Katia Rubio (org.), São Paulo, Laços, 2017, 260 pp. 
"ULISSES

O mito é o nada que é tudo. O mesmo sol que abre os céus É um mito brilhante e mudo O corpo morto de Deus,

Vivo e desnudo.

Este, que aqui aportou, Foi por não ser existindo.

Sem existir nos bastou. Por não ter vindo foi vindo E nos criou.

Assim a lenda se escorre A entrar na realidade, E a fecundá-la decorre. Em baixo, a vida, metade De nada, morre." (Fernando Pessoa)

\section{PRIMEIRO: TENTATIVA DE SÍNTESE}

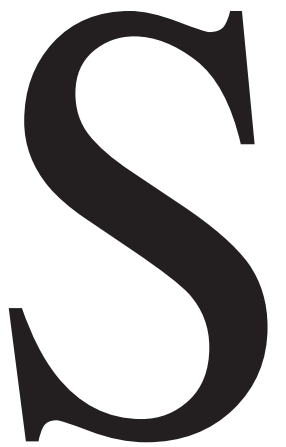

eja-me permitido atribuir o título, que encima este texto, ao esforço de apresentação do livro Esporte e mito. Do que é que este trata? Muito simplesmente de um conjunto

de 15 narrativas, artisticamente tecidas pela aprimorada voz ética e estética de aedos e arautos dotados de saber ampliado e experimentado, com carta de alforria para muito nos contar e encantar, nesta era crepuscular, tão carecida de matar a fome e sede de admiração e maravilhamento. Sejamos gratos! Ainda há quem porfie em trazer de volta e semear contos e lendas neste mundo árido, deserto e necessitado de confabuladores de enredos e sonhos. Ah, como precisamos de pintar o céu nos nossos olhos, de os encher e clarear com a presença das estrelas distantes, para não nos afundarmos no pasmo e na tristeza dos dias convertidos em noites!

É este o compromisso assumido e notavelmente consumado pela pluralidade e policromia de ensaios que não desistem de revestir o desporto contemporâneo com as roupagens do imaginário, da alegria dionisíaca, da lógica platónica e da Paideia homérica, dos princípios e valores ínsitos no mito dos Argonautas, nos desafios de

Neste texto foi mantida a ortografia vigente em Portugal.

JORGE OLÍMPIO BENTO é professor catedrático da Faculdade de Desporto da Universidade do Porto. 
Dédalo e na ousadia de Ícaro. A ementa não podia deixar de fora a meta da superação e sublimação pelo sacrifício, a arte relacional do treinador inspirada na inteligência e bondade de Quíron, o fado do atleta (e do ser humano) expresso no mito de Sísifo, o drama de ser suplente e a esperança de alcançar a titularidade, de saber esperar para abraçar a bem-amada Penélope.

O desporto não é só masculino; contém deusas e heroínas. Não é virtude espontânea; também o espreitam a tentação, a ilusão e o desengano. A trama humana reflete-se na acrópole desportiva; incumbe-lhe inventar e pôr à prova, constantemente, novos heróis, como os que despontam no enfrentamento das montanhas, das ondas do mar, das dificuldades e aventuras inerentes às forças da natureza.

Como se vê, o desporto tem muitas facetas e igualmente rostos. Os seus arquétipos espraiam-se para além do panorama tradicionalmente consagrado; pertencem ao Ocidente e Oriente, ao Norte e ao Sul. Ou seja, a humanidade inteira também respira, rejubila e realiza-se no desporto, através das prestações de todos quantos a integram, independentemente da cor da pele e local de nascimento e residência. Porque ele é um fenómeno antropológico e universal, desde tempos imemoriais.

Assim foi no passado, e assim é no presente. A atual conjuntura eletrónica não pôs fim ao mito; ele renasce e renascerá cada vez mais, qual Fénix emergente das cinzas, para continuar a irradiar um feixe de luz.

Aos 15 ensaios, acabados de resumir numa síntese insuficiente para levantar o véu da exuberante riqueza que os perfaz, acresce uma peça introdutória, cerzida pelo ourives das palavras e sentimentos, a pro- fessora Katia Rubio. Nela são expostas as diferentes parcelas do todo, semelhantes aos andamentos de uma composição musical que não cessa de inundar e dulcificar os nossos ouvidos com a harmonia de notas e passagens harmoniosas e maviosas. Para esse fim convergem palavras leves e aladas, que edificam uma genuína catedral gótica com os refulgentes vitrais. Deste jeito somos atraídos e convidados a levantar voo para as alturas da magnificência e sublimidade.

Creio, sinceramente, que bastavam os parágrafos anteriores para dar por concluída a mal conseguida tarefa de apresentação da obra. Porém, este gesto configuraria um ato de desamor da minha parte. Ora, nem o livro justifica o desfavor da falta de exaltação dos seus méritos, nem os autores são merecedores de uma indelicadeza, traduzida na contenção das minhas palavras. Assim, para não incorrer em desprimor e em ofensa à criatura e aos criadores, vou sobrecarregar os leitores com mais umas quantas considerações, correndo o risco de lhes provocar enfado. Peço-lhes que me relevem os excessos, em nome da bondade das intenções.

\section{SEGUND0: UMA OBRA POSICIONADA E SITUADA}

Sublinhemos, a obra vale por si mesma; não precisa de carta de recomendação para ser bem acolhida pelos leitores, nem de salvo-conduto para circular com o à-vontade próprio de quem é confiável e respeitável. Este livro constitui um mosaico de azulejos e ladrilhos primorosos; é realmente, parafraseando Jorge Luis Borges, "uma extensão da memória e da imaginação". Proporciona uma instigante pluralidade de caminhos e 
caminhantes, porfiadores na busca e descoberta de expressões da sabedoria e felicidade.

O território do percurso situa-se no país do desporto; contudo o alcance vai mais além, visando instituir padrões e balizas no mapa mundi da interpretação e configuração do sentido da existência. As páginas do livro, densas de acuidade e sensibilidade poética, adentram-nos a alma, derramando um intenso clarão, proveniente do casamento venturoso das inquietudes da psicologia e das habilidades e perguntas da filosofia. Esta parece ser a que mais dá a cara e põe de fora o pescoço e o nariz; mas é aquela que a espicaça.

Já estou a pressentir a estranheza e a interrogação dos "cientistas" oficialmente encartados e embasbacados! Justifica-se evocar mitos num tempo de absolutismo do conhecimento científico? A resposta encontra-se na hodierna realidade da vida e do contexto social.

Inegavelmente, o mundo mudou muito; melhor dizendo, foi muito mudado, porquanto não muda espontaneamente, mas, sim, como resultado da ação intencional dos que nele intervêm. Ora, a mudança para melhor, em vários parâmetros, é acompanhada de não poucas manifestações de ansiedade e descontentamento, que trazem de volta a necessidade de acordar, avivar e reacender mitos e utopias. Continuam por inventar remédios para as dores mudas; e estas não cessam de alastrar, imersas na torrente de liquefação da Modernidade, cujo legado julgávamos sólido e duradoiro. Os ventos do efémero, do superficial e volátil, da aridez e desertificação sopram descontrolados e inclementes de todos os lados, como se o nosso mundo fosse uma caixa de Pandora totalmente esburacada e sem qualquer possibilidade de instalar fechaduras nas portas e janelas.

A conclusão é óbvia: por maior que seja a tentativa de destruir os mitos, ela revela-se inglória. Os mitos são indestrutíveis; a sociedade, que os tenta destruir, é a mesma que os renova. Se dúvidas houvesse, bastaria olhar e analisar atentamente a nossa contemporaneidade, tão apostada em abater os referenciais do passado. Ela esfalfa-se em impor o mito científico-tecnológico ou tecnocrático; paradoxalmente, ao mesmo tempo e em igual medida, reconstrói o capital mitológico de antanho, por força da enorme crise de valores e de sentido da vida que engendra e agudiza.

É neste ponto que o livro entra em cena. Constitui um tratado de posicionamentos contra a subversão da memória; melhor dizendo, introduz a memória no nosso tempo, para que não sejamos navegadores sem a bússola da consciência. Por isso, cuida de nos falar do desporto e das suas virtualidades, queimadas pela voracidade dos fogos desta era demencial, em que somente há vencedores e perdedores num jogo de soma zero.

O desporto lembra-nos que o Homem apenas é compreensível na perspectiva de uma aventura que se vai revelando e constituindo pouco a pouco. Aviva as exortações de Píndaro (521-441 a. C.):

- Sê quem és! Sê o sonho e a ideia de Homem que transportas dentro de ti! Sê o Ser que nunca se é! Tenta ser o que não podes ser!

- Não creias, alma querida, na vida eterna: Mas esgota o campo do possível! Nada nos dispensa da obrigação de tentar transpor a nossa pequenez e de nos levantarmos do chão. Sob pena de sermos atingidos pelo 
severo julgamento de Xenofonte (cerca de 427-355 a. C.): Que desgraça para um homem envelhecer sem nunca ter visto a beleza e a força de que é capaz o corpo!

Sim, o desporto mantém vigente o mandamento de cuidar afincadamente do ser inconcluso e inacabado (Octavio Paz, 1914-1998), de procurar dar forma sempre mais aprimorada e renovada à plasticidade da nossa arquitetura exterior e interior, de mostrar por fora a estatura e o brilho da pessoa de dentro. Inscreve-se na postura de Fernando Pessoa (1888-1935): "Sou definitivamente contra o definido, porque o definido é o bastante e o bastante não basta".

Nas respostas dadas por Odisseu ou Ulisses à capitosa deusa Calipso, que o prendeu nas teias do amor ardente, durante cerca de seis meses na ilha de Ogígia, encontra-se exarado um compêndio de vida: "Viver com lucidez é melhor do que ser imortal! Mais vale uma vida bem-sucedida de mortal do que uma vida malsucedida de imortal!". A vitória sobre o medo e a própria finitude é a solução para escapar ao terrível destino dos mortais: uma vez mortos, tornam-se "anónimos", ficam "sem nome".

$\mathrm{O}$ desporto funda-se e filia-se nos postulados anteriores: na obrigatoriedade de beirar o impossível, de contribuir para a condução e salvação da vida "correta" e "boa" de seres mortais, mas inquietos, mediante a realização de proezas incomuns, "excessivas" e extraordinárias, "artísticas" e virtuosas, merecedoras de admiração, apreço, respeito e recordação dos outros, inclusive para além da morte.

A máxima, prescrita por Píndaro, prolonga-se noutra do mesmo autor: "O atleta é aquele que se compraz com o esforço e o risco". É precisamente isto que constitui o desporto e é constituinte de nós, expressão do nosso ser. Suportamos este desafio e destino, o peso do sentido da vida e da existência.

Os humanos, porque somos e nos sabemos frágeis e precários, transitórios e sujeitos à finitude, ansiamos e procuramos alcançar e beber a taça do mundo.

Os deuses, porque são eternos e omnipotentes, não necessitam de realizar façanhas que concitem a admiração dos semelhantes e projetem o seu nome para a eternidade, mas não conseguem deixar de sentir nostalgia daquela taça. Por isso Homero, na Ilí$a d a$, imagina-os a competir entre si, fazendo apostas acerca do vencedor, na corrida de carros celebrada frente à Troia, durante as exéquias de Pátroclo.

Os humanos praticam a única coisa que os deuses não se atrevem a fazer: arriscar-se ao fracasso, ao insucesso, à dúvida, à tensão, desilusão e derrota. Eles somente sabem que podem ganhar. Nós nascemos predestinados a assumir o risco de perder, nascemos para cumprir o destino e o fado de ganhar algumas vezes, de perder muitas outras e de ter que aprender a perder e suportar a derrota, sem perder a face, a determinação e o gosto de insistir, treinar e competir, de intentar e ousar, de melhorar e progredir. Chama-se a isto vencer, viver e existir, conferir sentido à existência.

Será isto pouco? Não é o suficiente; todavia, representa o máximo que nos é permitido alcançar. Não temos concessão para mais.

Como indicou o Padre António Vieira (1608-1697), “para aprender não basta só ouvir por fora, é necessário entender por dentro". Observemos, pois, atentamente! Por detrás do mito esportivo, descobrire- 
mos muita gente famosa que abriu os caboucos para edificar a humanidade. Olhem bem e verão Moisés (1592-1472 a.C.), Buda (c. 566-478 a.C.), Confúcio (551-479 a.C.), Lao-Tsé (séc. VI ou IV a.C.), João Baptista (2 a.C. - 30 d.C.), Jesus Cristo, Francisco de Assis (1182-1226) e tantos outros!

Emergem esses e muitos mais que apontaram vias do agir perfeito, de transcendência e superação, de humanização e divinização, de edificação da humanidade, através de heroicidades, de feitos, de lendas, de mandamentos, metáforas, parábolas, evangelhos e sermões. Emergem todos os que se amarram à tentativa denodada de desacorrentar Prometeu, de lhe libertar os pés e as mãos, a cabeça e a mente, a emoção e a razão, as expressões e feições, o riso e o sorriso. Entre eles estão os poetas e vates que são "educadores de $1^{o}$ grau"; e os rapsodos, pedagogos e filósofos que são "educadores de $2^{\circ}$ grau". Foram eles que criaram os mitos e educaram a Grécia. São eles e as suas criações que educam os povos e nações ${ }^{1}$.

Enfim, filiado no mito prometeico e na matriz judaico-cristã, o desporto é um palco de acometimentos transbiológicos, situados para além dos imperativos do quotidiano. Um campo de demonstração da extraordinária capacidade do ser humano e do seu corpo. Correspondendo à exigência de que a humanidade também se cumpre e tem que cumprir através de prestações corporais. $\mathrm{Ou}$ seja, o corpo não escapa ao destino de superação e transcendência.

A questão existencial é evidente, e a ela consagram-se os capítulos do livro: a de des-

1 Manuel Patrício, No labirinto messiânico de Fernando Pessoa, Sintra, Zéfiro, 2013, p. 88. vendar o significado de uma atividade, no caso o desporto, na qual os humanos despendem muito tempo. Esta procura nunca acaba, porque o resultado jamais será cabal ou, sequer, satisfatório. Jamais lograremos apoderar-nos do segredo da vida feliz, escondido dos humanos pelos deuses. Aquilo de que precisamos para cumprir a vida num plano superior, por nossa conta e risco, com o fogo do espírito, das artes, das ciências e das "técnicas" (à luz do significado etimológico que o termo grego techné encerra), esse prontuário de receitas jamais o obteremos em quantidade bastante.

Os deuses são nossos rivais; somos irremediáveis concorrentes. A felicidade deles parece implicar a nossa desgraça; e a nós faltam-nos o arrojo e a determinação de Prometeu para escalar o céu e usurpar aquilo que é propriedade divina. No entanto, se renunciarmos a enfrentar esta busca e repto, de triunfo impossível, condenamo-nos a ser prisioneiros do labirinto de Dédalo e a ser devorados pelo insaciável Minotauro. É contra esta desdita que o livro nos alerta, e apresenta o revigoramento do teor mítico do desporto, investindo nele a função salvífica de Teseu.

No desporto participamos na construção de identidades cujo ego é um espírito encarnado, uma tatuagem corpórea da alma. Ocupamo-nos da apropriação e irradiação de ideais e símbolos imanentes a artes performativas, que formam quem as executa e quem as observa. Entregamo-nos à instalação e à institucionalização de conceitos e preceitos, deveres e obrigações, ilusões e utopias. Aderimos a uma cultura de metas e compromissos, de dificuldades e desafios, de hábitos e rotinas de trabalho para lá chegar.

$\mathrm{E}$ assim procuramos anular as fronteiras entre a alma e o mundo exterior; lavramos 
no esforço severo, incansável e sistemático de projetar a nossa natureza, nomeadamente o corpo, contra si própria, para além e acima de si mesma, convidando-a a não se dar por satisfeita com o seu estatuto, a suplantar-se e a chegar-se a níveis para os quais não se apresenta como particularmente predestinada.

Por conseguinte, renunciar ou afrouxar na observância dos seus princípios e valores equivale a empobrecer os cidadãos nas dimensões técnicas e motoras, éticas e estéticas, cívicas e morais, e a favorecer a proliferação do laxismo e relativismo, do clima relaxado e indolente. Ao invés, é imperioso investir no aperfeiçoamento do comportamento gestual, ético, estático e moral - tanto ou mais do que no progresso científico e tecnológico!

\section{TERCEIRO: POR QUE E PARA QUE 0 REGRESSO AO PASSADO?}

O livro desperta-nos para a reflexão e a ação, numa altura em que o espetáculo desportivo, devido à sua comercialização, vê perturbada a sua matriz identitária, alterado o equilíbrio de muitas das suas teses e interpretações, e descartados mitos com os quais conviveu muitos anos.

Como alerta José M. Constantino, "a defesa do desporto é, também, isso. A avaliação do capital de experiência que a história do desporto acumulou [...] Um capital de experiência que é contraditório: tem aspetos positivos ao lado de negativos"2.

2 José Manuel Constantino, Em defesa do desporto - mutações e valores em conflito, Coimbra, Edições Almedina, 2007.
Como quer que seja, temos o dever da inovação; e de perceber que novo somente é o eterno. Pego nesta asserção e coloco-me na pele da desconfiança e do ressabiamento dos "reformistas mercadológicos" para lançar uma provocação aos autores do livro. Estes surgem como Matusaléns, afetados pela senectude, apostados em reeditar o passado num tempo que tem horror por ele, o trata como algo tenebroso e se consome no namoro obsessivo do presente e do futuro.

Mas... serve ou não para alguma coisa o regresso ao passado? Bem, recorrendo ao escritor britânico Leslie Poles Hartley (1895-1972), o passado é um país distante e estranho, onde se fazem muitas coisas de forma diferente. Por outras palavras, a recordação do passado aviva e disponibiliza a possibilidade de escolhas, sobretudo de natureza ética e moral. O que abana as folhas da árvore de identidades fugazes, de "novidades" e modas sem raízes.

$\mathrm{O}$ facto de vivermos no presente e de estarmos presos a ele não nos obriga a declarar que ele é fascinante e o futuro será ainda melhor; como se sabe, a surpresa é a essência da história. O olhar retrospetivo contém potencialidades não negligenciáveis. Com efeito, o passado não é um fundo arqueológico morto; contém instrumentais para ajudar a necessidade de perceber e equacionar os conflitos do presente, oferece exemplos e modos de ação, quer para comparações e opções, quer para evitar comédias que acabam em tragédias. Talvez seja este aspeto que leva não pouca gente a encarar o passado como algo deveras incomodativo e maçador. É que ele coloca limites malditos a quem quer ter todo o espaço aberto somente para ganhos e vantagens, sem qualquer escrúpulo ou entrave: o saber e a experiência, 
adquiridos com a vida e trabalho árduos, em vez da boçalidade e ignorância agressivas, a virtude em vez da frivolidade e sordidez, o dever, a exigência e a normatividade em vez do facilitismo e laxismo, a honradez e verticalidade em vez da fraude e debilidade do carácter, a modéstia e responsabilidade em vez da vaidade e leviandade, o respeito em vez da ordinarice, a dignidade em vez da indecência, a compaixão em vez da indiferença, o altruísmo em vez do desdém, a memória seletiva em vez das trevas do esquecimento, a prudência em vez do voluntarismo, o parar para pensar em vez do imediatismo, a verdade em vez da falsidade, da esperteza e do vale-tudo ${ }^{3}$.

Não se advoga o regresso à lamparina de azeite ou petróleo e a outros utensílios afins. Porém não é dispensável a candeia perscrutadora de Diógenes, se quisermos lobrigar na feira da gente o homem capaz de agir, pensar e falar fora da caixa do senso comum, de iluminar a vida com as estrelas dos atos e palavras, das causas e ideais, dos princípios e valores.

Sopesemos a tese de George Orwell (1903-1950): "Quem controla o passado dirige o futuro. Quem dirige o futuro conquista o passado" ". E um testemunho semelhante do Padre António Vieira (1608-1697): “Os exemplos dos tempos passados costumam ser as regras e documentos para os presentes e futuros".

Queira-se ou não, quando nos perdemos e tresmalhamos nos desatinos do presente de uma sociedade notoriamente desorientada, a

3 José Pacheco Pereira, "Mas qual é o mal do passado?", in Público, 9/12/2017, p. 44.

4 "Escrito na pedra", in Público, 26/1/2017, p. 45. alternativa que nos resta é ir ao encontro dos caminhos abertos pelo passado. A viagem conduz à criteriosa avaliação do presente e deságua, por isso, em constatações e balanços. De onde viemos? Quais os caminhos percorridos? Para onde e como estamos a ser levados? Para onde queremos caminhar?

Com isto pretendo enfatizar que, neste livro, sobressai um apurado conhecimento do passado (Antiguidade grega e Modernidade) e das suas forças motrizes, suscetível de regenerar o presente e de gerar um futuro frutificado pelo domínio atualizado e inovador do pensamento, dos conceitos, noções, princípios, ideais e valores dos tempos idos. Os autores entregam-se à recriação de mitos e utopias, como quem reabre vias, que se foram fechando paulatinamente, para nelas voltarmos a transitar. Assumem, desse modo, a função de docentes universitários, cientes do compromisso implícito no estatuto de intelectuais. Tal compromisso intima a retomar as esperanças, exaltações e promessas do passado, frustradas ou por cumprir, a projetar de novo o espírito que as iluminava, a reinventar um discurso e propósito de âmbito geral, suscetíveis de serem compartilhados pelos discursos e propósitos especializados.

O desporto nasceu no berço e ventre da Antiguidade clássica; e recebeu aleitamento da Modernidade, do Humanismo e Iluminismo. Se for deserdado daquele nascimento e perder a bússola humanista e iluminista, tomará um rumo assaz perigoso, em direção ao naufrágio.

Passados tantos séculos, é curial olhar para o ideal desportivo dos gregos com as lentes aumentativas de Píndaro: “Olímpia, mãe dos jogos de áureas coroas, senhora da verdade". E igualmente admirar o impacto 
que esse ideal causava nos povos de antanho, fazendo fé na observação de Tritantaicmes, um conselheiro de Xerxes, rei dos persas, procurando demovê-lo de invadir a Grécia.

Ao ser informado de que o prémio do vencedor dos Jogos Olímpicos era uma coroa e não dinheiro, Tritantaicmes não conseguiu ficar calado e proferiu em público esta declaração: "Ai, Mardónio, que homens são esses contra quem nos levas a combater, se eles não lutam pela riqueza, mas só pela superioridade!". O seu parecer sensato implorava: Por favor, Mardónio, não nos leves a combater essa gente que luta por ideais, pela glória, pela coragem e por valores superiores! ${ }^{5}$

Enfim, o ideal desportivo dos gregos encerra a luta eterna pelo espírito de liberdade, expresso nos versos sublimes do poeta Lord Byron (1788-1824):

"As montanhas olham para a Maratona E Maratona olha para o mar;

E ali meditando uma hora sozinho,

Sonhei que a Grécia poderia ser ainda livre; Porque ali de pé sobre o túmulo dos persas Não me pude julgar um escravo".

\section{QUARTO: EM JEITO DE CONCLUSÃO}

É disto e de muito mais que o livro trata. Os autores tocam nos desafios do desporto contemporâneo fazendo um périplo pelas origens axiológicas e matriciais; e convidam-

5 A notícia do apelo feito pelo conselheiro Trintantaicmes a Xerxes (518-465 a.C.), rei dos persas, deve-se a Heródoto de Halicarnasso (século V a.C.), considerado o pai da História (Arte antiga, obras de Maria Helena da Rocha Pereira, Coimbra, Imprensa da Universidade de Coimbra, 2016, p. 40). -nos a embarcar e a ser partícipes ativos do cometimento. Trazem à luz do dia "coisas" tidas por velhas e caducas, que, afinal, não estão gastas; ao invés, continuam a ser fontes, donde jorra inspiração abundante para a educação hodierna, tão carecida de vias arrojadas e inovadoras, tal a crise de orientações que a lavra.

As páginas e a trama do livro são uma caixa de ressonância do incitamento que Ulisses, na Odisseia, dirige aos seus marinheiros, durante uma inclemente tempestade:

"Rema forte comigo, valente companheiro! $\mathrm{O}$ vento, que nos açoita o rosto, é o mesmo que impulsiona as nossas velas até Ítaca. A chuva, que se crava no nosso corpo como dardos afiados, é a mesma que disfrutamos nos areais escaldantes das praias. Rema forte! Se fraquejarem as forças com as quais, na juventude, movíamos os céus e a terra, serão os nossos heroicos corações que nos levarão até à grande Ítaca".

Ulisses não somente navegou com esperança, otimismo e valentia; também conseguiu chegar a Ítaca. Inspiremo-nos na mensagem de confiança, que contagiou os autores do livro e eles ampliam e fazem chegar até nós. Colhamos nela a determinação de seguir em frente.

$\mathrm{O}$ objetivo de quem não se sujeita à obscuridade e fealdade do presente é igual ao que emana da alma, lucidez e vontade destes nossos abnegados e corajosos companheiros de caminho, resistentes às duras provas e fustigações da cega incompreensão. Cumpre-nos, portanto, reverenciá-los com gratidão e corresponder-lhes, tanto quanto possível, com modalidades adequadas da nossa ação. 
Fomos no passado, temos que ser no presente e futuro o Homo sacer, inconformado, interrogativo, faminto e sedento de conhecimento, de saber e verdade. Assumamos, aqui e agora, a nossa parte no descobrimento e colonização da idealidade, tendo em boa conta a advertência de José Saramago (1922-2010): "Somos a memória que temos e a responsabilidade que assumimos. Sem memória não existimos, sem responsabilidade talvez não mereçamos existir".

Não fiquemos paralisados diante de factos absurdos e irrazoáveis, por mais inevitáveis que pareçam! Compete-nos renovar o desporto, como fator da dignificação e elevação do mistério da vida. Eis o ensinamento colhido na peregrinação que o livro Esporte e mito nos levou a fazer ao passado! 